\title{
ПЕРВАЯ АГРАРНАЯ ПРОГРАММА КОНСТИТУЦИОННО-ДЕМОКРАТИЧЕСКОЙ ПАРТИИ
}

\author{
Тнсситуционно-Демократическая Партия была создана в октябре \\ 1905 года на съезде российских либералов. Тогда же была принята \\ - и ее программа. Хотя крестьянский вопрос на съезде практически не \\ обсуждался, - главное внимание делегатов было сконцентрировано на орга- \\ низационных вопросах, он занял в программе видное место. В её шестом \\ разделе «Аграрное законодательство» предполагалось:
}

36. Увеличение площади землепользования населения, обрабатывающего землю личным трудом, как-то: безземельных и малоземельных крестьян, а также и других разрядов мелких хозяев-земледельцев - государственными, удельными, кабинетскими и монастырскими землями, а также путем отчуждения для той же цели за счет государства в потребных размерах частновладельческих земель с вознаграждением нынешних владельцев по справедливой (не рыночной) оченке.

37. Отчуждаемые земли поступают в государственный земельный фонд. Начала, на которых земли этого фонда подлежат передаче нуждающемуся в них населению (владение или пользование личное или общинное и т.д.), должны быть установлены сообразно с особенностями землевладения и землепользования в различных областях России.

38. Широкая организачия государственной помощчи для переселения, расселения и устройства хозяйственного быта крестьян. Реорганизация межевого дела, окончание размежевания и другие меры для подъема благосостояния сельского населения и улучшения сельского хозяйства.

39. Упорядочение законом арендных отношений путем обеспечения права возобновления аренды, права арендатора, в случае передачи аренды, на вознаграждение за произведенные, но не использованные к сроку затраты на улучшения, и учреждение примирительных камер для регулирования арендной платы и для разбора споров и несогласий между арендаторами и землевладельиами. Открытие законного пути в судебном порядке для понижения непомерно высоких арендных цен и уничтожения носящих кабальный характер сделок в области земельных отношений.

40. Отмена действующих правил о найме сельских рабочих и распространение рабочего законодательства на земледельческих рабочих применительно к техническим 
особенностям земледелия. Учреждение сельскохозяйственной инспекции для наблюдения за правильным применением законодательства по охране труда в этой области и введение уголовной ответственности сельских хозяев за нарушение ими законодательных норм по охране труда ${ }^{1}$.

После окончания съезда, 18 октября 1905 года, состоялось заседание Центрального Комитета партии. Крестьянский вопрос и здесь не обсуждался. Однако Александр Яковлевич Хоментовский коснулся этой проблемы и сказал, что к «программе крестьяне отнеслись сочувственно, но землевладельцы ее провалили»². Это было не удивительно потому, что кадеты предлагали отчуждение частновладельческих земель.

На расширенном заседании ЦК 12-14 ноября 1905 г., был поднят крестьянский вопрос. Первым выступил Андрей Иванович Шингарев, который указал на необходимость «изменения аграрной программы» и обратил внимание на то, что непосредственно «с крестьянами придется об этом толковать». Прежде всего «надо на 1-й план выдвинуть» отчуждение частновладельческих земель, чтобы крестьяне приняли участие в съезде. Александр Александрович Стахович также говорил о желательности иной редакции аграрной программы, потому, что «крестьяне не согласились подписать программу» именно из-за неопределенности аграрной программы. Георгий Викторович Филатьев, представитель Области Войска Донского, поддержал Шингарева: «аграрную программу необходимо пересмотреть».

Но всё-таки единодушия в ЦК по этому вопросу не было. Так, Алексей Александрович Свечин доказывал, что

черниговские крестьяне будут довольны аграрной программой. Черниговский крестьянин - индивидуалист. Собственность не только средство для жизни, казаки боятся за свои земли, и они беспокоятся относительно судьбы своих земель. То же крестьяне. Крестьяне на губернском комитете настаивали на допущении продажи крестьянских земель.

П.Д. Долгоруков считал, что «решение аграрного вопроса» должно быть «предоставлено народным представителям». Он представил и схему выборов делегатов на съезд: «2 земца, 1 горожанин, 3 крестьянина и освобожденцы».

Кн. Евгений Николаевич Трубецкой говорил, что кадетской партии нужна новая аграрная программа, ибо некоторым принятая на первом съезде «показалась слишком умеренной». С этим согласился Леонид Николаевич Новосильцев, подчеркнувший, что кардинальный вопрос для кадетов «вопрос аграрный - в этом всё, без его решения будем висеть в воздухе».

${ }^{1}$ Государственный Архив Российской Федерации в Москве (ГАРФ) ф. 102 Департамент Полиции, оп. 1905, д. 999 часть 43, Программа Конституционно-Демократической Партии выработанная учредительным съездом партии 12-18 октября 1905 года, л. 88.

${ }^{2}$ ГАРФ, ф. 523 Конституционно-Демократической Партии, оп. 1, д. 27, л. 9. 
Владимир Андреевич Оболенский указал на «важность агитации среди крестьянских масс» на выборах в Государственную Думу. Его поддержали Иван Никифорович Овчинников и Василий Андреевич Караулов, считавшие, что «базой действий» должно быть крестьянство, при этом второй обратил внимание, что «лозунг крестьян - свобода, бог и царь».

Александр Яковлевич Хоментовский, заметил, что в партию «не идут ни частные землевладельцы, ни крестьяне», поэтому он был против слов в аграрной программе «в потребных размерах», - «нужно или все, или ничего».

Попову программа понравилась, однако, он считал, что для успеха партии на выборах, надо выставлять «программу как программу - минимум», а в аграрном вопросе требовать национализации земли. Попову возражал Наум Иосифович Файвишевич из Терской области, говоривший, что «национализация земли ограбила бы народ». Алексей Аресеньевич Зубрилин не был «удовлетворен программой не потому», что в ней не было «национализации земли, а потому», что не было «выражено ясно», что кадеты направлялись «в сторону интересов трудящихся масс. С ней можно однако же выходить в народ». Он также доказывал, что «в партию должны входить крестьяне - чтобы не менее 1 делегата от крестьян на съезд».

Федор Андреевич Щербина из Кубанской области, убеждал, что аграрную «программу надо переработать, особенно для разных мест». Кроме того, название партии «должно быть изменено: народническая партия, а члены - народники». Это предложение поддержал И.Н. Присецкий из Полтавской губернии, указавший, что надо назвать партию народной, и что «аграрная программа для местных условий (особенно для киргизов) не пригодна». Алихан Нурмагометович Букейханов тоже говорил о киргизах. «Правительство старается отнять у киргизов землю - отсюда аграрный вопрос. Необходимо определенно высказаться по этому вопросу. Тоже есть кабинетские земли, издавна (более 100 лет) занятые киргизами».

С.И. Лопацинский из Виленской губернии, высказался против национализации земли. Крестьяне примкнут к кадетом, «если программа будет более определенно выражена в смысле возможности прирезок», при этом следовало дополнить программу, имея ввиду местные предложения. Он также поддержал предложение об изменении названия партии на «народническую партию». Максим Моисеевич Винавер согласился с Лопацинским, что «аграрная программа должна быть приноровлена к разным местностям» и просил сообщить в ЦК «соображения не позже 3-х недель, чтобы комитет мог разработать этот вопрос к съезду». Алексей Алексеевич Муханов и Георгий Викторович Филатьев предлагали аграрный вопрос «предоставить усмотрению местных групп». В том же духе высказался Василий Николаевич Линд, который сказал, что следовало «из программы брать то, что нужно для каждой местности». 
Поводя итоги дискуссии, лидер кадетов Павел Николаевич Милюков «предложил выработать особую крестьянскую программу»³. Однако ЦК не принял определенного решения.

5-11 января 1906 года в Петербурге работал второй съезд Конституционно-Демократической Партии. Зал Тенишевского училища был переполнен делегатами и публикой. По словам Александра Александровича Кизеветтера, съезд «имел большое значение для партии» ${ }^{4}$ В своём программном докладе Иосиф Владимирович Гессен указал, что

\begin{abstract}
на первом месте здесь стоит аграрный вопрос. Дума собирается в апреле, а с началом весны, несомненно, опять широко разольется аграрная волна, которая, несомненно, сильно отразится на всем освободительном движении. Как бы ни смотреть нажелательность и нежелательность вмешательства классовой Думы в этот основной вопрос русской социальной жизни - совершенно немыслимо себе представить, чтобы в то время, как все основы деревенской жизни будут потрясены, Дума могла спокойно обдумывать план будущего здания, не обращая внимания на разрушение самого фундамента. Исходя отсюда, Центральный Комитет партии и выдвинул особо аграрный вопрос, по которому съезду и будет представлен доклад, намечающий схему его временного разрешения 5 .
\end{abstract}

Затем была избранная комиссия, на заседаниях которой обсуждался аграрный вопрос, а 7 и 8 января, на пленарном заседании съезда были представлены результаты ее работ и состоялась дискуссия. С докладами выступили кн. П.Д. Долгоруков и Александр Аркадьевич Кауфман. Первый, выступая от имени комиссии, сообщил, что она пришла к выводу, чтобы «совсем не менять программы, или допустить лишь малые изменения». Основанием этого служило и короткое существование партии, и то, что выработанная программа удовлетворяла население. Замечания по существу отразили две точки зрения: одни видели в решении «аграрного вопроса осуществление коллективизма», другие его боялись. Комиссия представила следующие замечания по программе: «1. Недостаточность термина «потребное количество» (земли Э. В.); 2. Неопределенная «справедливая оценка»; 3. Замечания относительно форм землепользования и 4. Недостаточно выясненная важность интенсификации!». Далее Долгоруков информировал дпелегатов, что аграрная комиссия предложила выяснить, что значит термин «по справедливой оценке». Справедливая оценка не предполагала «только интересы помещиков. В расценку должен входить чистый доход, определяемый в каждой местности особыми арбитражными комиссиями». Цена земли должна была определятся «нормальной средней доходностью, причем не должны

3 Протоколь Центрального Комитета Конституционно-Демократической Партии, t. 1, 1905-1911 г2., Москва 1994, с. 35-41.

4 А.А. Кизеветтер, На рубеже двух столетий. Воспоминания, 1881-1914, Москва, 1997, с. 279.

${ }^{5}$ Съезды и конференции Конституционно-Демократической Партии, t. 1, 1905-1907 гг., с. 72. 
приниматься в расчет арендные цены». При этом оратор предложил внести в программу следующее пояснение: «Под справедливой оценкой следует понимать цену земли сообразно нормальной местной доходности земли при обработке своими средствами и силами, не считая арендной платы». По его мнению, «частновладельческие земли должны быть» отчуждены до определенного минимума. Относительно пункта 37 аграрной программы комиссия высказалась в том смысле, что хотя государственный фонд и предполагалось ввести, но индивидуальная частная собственность допускалась. «При арендном землепользовании» имелась «в виду выкупная система, но обязательного отчуждения» не должно быть, должны быть введены «только ограничительные меры против концентрации земель. Вообще же отвод земли в частную собственность будет совершаем лишь по требованию населения». Выработка норм справедливой оценки выдвигала «на первый план арбитражные комиссии», которые должны были «состоять из местных общественных деятелей и крестьянских представителей. Но помимо этой аграрной комиссии необходимо еще образование местных комиссий по губерниям». В итоге, комиссия предлагала:

1) Признать, что иена земли определяется по нормальной для данной местности доходности при условии самостоятельного ведения хозяйства, не принимая во внимание арендных плат, созданных земельной нищетой. 2) Признать, что отвод земли на правах ограничения собственности возможен в местностях, где того требует население. 3) Образовать аграрную комиссию при Центральном Комитете партии. 4) Образовать местные комиссии по губерниям ${ }^{6}$.

А.А. Кауфман в начале представил съезду соображения комиссии по поводу пункта 36 программы партии. Комиссия «желала бы довести наделение крестьян землею до нормы, достаточной занять весь труд крестьянина и его семьи». Но «это пожелание совершенно неосуществимо». При этом он напомнил, что

существуюший надел достаточен занять лишь 23\% трудоспособных крестьянских семей, 77\% остаются незанятыми. Следовательно, размеры крестьянского надела необходимо более чем учетверить. Но об этом не приходится даже мечтать.

Можно было бы довести надел до нормы принятой в 1861 г., тогда

нужно 75 млн. десятин. Если обратить все земельные угодья в крестьянский надел, получится около 50 млн., не хватает, таким образом, около 27 млн. десятин.

${ }^{6}$ Съезды и конференциии Конституичонно-Демократической Партии, t. 1, 1905-1907 г2., c. 128,131 . 
Все это крайне ничтожно по сравнению с потребностями, поэтому нужно

прирезать много миллионов десятин, чтобы при существующих условиях крестьянин мог существовать безбедно.

Необходимо иметь ввиду, что переселение невозможно, им нельзя даже задержать естественный прирост населения. Местные комиссии, в состав которых должны входить представители власти, крестьян, землевладельцев и земства будут решать «сколько нужно дать, кому дать, до чего можно довести надел» имея ввиду местные нужды, при этом их решения «должны быть согласованы с общегосударственными интересами». Кауфман полагал, что «невозможно обратить всю землю в крестьянские хозяйства», ибо это повлекло бы «за собой варваризацию культуры. Нужно различать интересы» крестьянства и «всеобщее народное благо», а положение «крестьян может быть улучшено не только прирезкой, но и повышением культуры и введением правовых норм». Затем он коснулся вопроса об общинном землевладении. По его мнению, «этот вопрос очень спорный, связанный с местными условиями», поэтому не «можно насиловать волю населения» и кадеты не могут соглашаться со взглядом «о снятии пут общины». Что же касается вопроса об отчуждении земель, то необходимо было бы решить вопрос, ибо «если до весны крестьяне не будут наделены землей, то вспыхнут аграрные беспорядки». Потому «теперь речь идет не о коренной реформе, а только лишь об успокоении. Но, принимая разные меры, нужно по крайней мере принимать их, не вредя. Мужик пухнет от голода везде». Прежде всего «улучшение должно быть достигнуто на земле», чтобы увеличивалось количество питания, то есть «получение с десятины вместо 40 пудов 100 пудов зерна. При современном положении дел сохранение крупного землевладения очень важно». Кадеты не хотели «сохранить латифундии», но «должен быть установлен некоторый максимум владения». Резюмируя, Кауфман сказал, что невозможно доведение крестьянского землевладения до размеров вычисленных рабочих норм и до норм 1861 г. Нужно создать земельный фонд, в состав которого будут входить все земли «казны и уделов в Европейской России», а также «земли в Азиатской России» для переселенцев. Частновладельческие земли, сдаваемые в аренду должны подлежать немедленному отчуждению. Распределением «между нуждающимся в земле населением должны» заниматься «местные комиссии из представителей» земств, крестьян, землевладельцев и власти ${ }^{7}$

${ }^{7}$ Съезды и конференщии Конституционно-Демократической Партии, t. 1, 1905-1907 г2., c. 128-130, 137-138, 145-146. 
После докладов состоялись прения, «продолжительные дебаты», по определению А.А. Кизеветтера. Максим Михайлович Медиш, делегат из Харькова, сказал, что «К крестьянам надо обращаться честно и говорить им прямо, что в действительности мы можем им дать, не обещая», как то делали другие партии, ибо не получивши обещанного, «крестьяне будут глубоко разочарованы в нашей партии». Затем в вопросе

в каком размере необходим надел, нужно исходить только из той нормы, чтобы крестьянин был сыт, но ни из какой другой.

Оратор видел обострение крестьянского вопроса в том, что в 1861 г. «на душу приходилось 4 десятины, а в 1900 г. уже 2,6 десятины». Кадетская партия соглашалась с тем, что

необходимо наделить землей, но при существующей производительности крестьянского хозяйства ее нет столько, чтобы покрыть даже элементарные потребности, чтобы народ не пух и не умирал с голода. Беззаботность правительства с 1861 г. привела к тому, что теперь уже не до комиссий, а приходится удовлетворять крестьян сейчас же. Время не ждет, и, если крестьяне не будут убеждены, что им дадут землю, этой же весной произойдут события, перед которыми побледнеют события прошлого года.

В.М. Владиславлев, делегат из Симбирска, убеждал, что надо «ввести национализацию земли для того, чтобы не вернуться к прежним условиям. Еще в исторических актах взгляд крестьян на землю выражался словами: Божья, ничья, общая». Потому «всю землю нужно собрать в один мешок и из него раздавать».

По мнению Ф.А. Березова, делегата из Саратова, крестьяне «не одобрят того пункта программы», который требовал «лишь частичного отчуждения земель». Поэтому Павел Сергеевич Усов из Москвы считал, что могли бы «быть отданы крестьянам громадные латифундии, а не мелкие имения». Он указывал

на пробел доклада ЦК, где не указана максимальная допустимая норма землевладения, при условии, что часть земли, дающая превышение нормы, подлежит безусловному отчуждению.

Вячеслав Евгеньевич Якушкин, делегат из Курска, сказал, что задача партии «содействовать успокоению страны» и кадеты, оставаясь на почве этой программы, вряд ли будут иметь успех среди крестьян. Подвергая критике доклад А.А. Кауфмана, он считал «необходимым его отвергнуть», ибо предложенные меры были запоздалыми. 
Смолин, делегат из Рязани, будучи мелким крестьянином, доказывал, что если кадеты не пойдут

навстречу измученному, изголодавщемуся народу, то партия наша будет тащиться в хвосте всего движения. Все, что партия ставила на своем знамени, она должна провести. Если мы хотим служить народу, то должны пойти навстречу всем его желаниям.

Минас Иванович Берберов, делегат из Ростова на Дону, считал программу по аграрному вопросу «слишком эластичной, что особенно неудобно в дебатах с представителями других партий» и полагал, что необходимо было

1) указать, что партия одинаково относится к владению общинному и частному, указать на ограничение владения землей; 3) указать на необходимость передачи войсковой земли не только казакам, но и крестьянам.

Лев Иосифович Петражицкий из Петербурга говорил, что наделение крестьян «землей не есть решение аграрного вопроса»: через несколько лет снова «наступит нужда и голод». Его надо решить так, чтобы люди уходили из деревень в другие сферы производства как на Западе, где население, сидящее на земле, уменьшалось. Оратор понимал, что лозунг наделения землей был выдвинут в программе как «необходимость потушить пожар недовольства».

Николай Николаевич Черненков, член ЦК, видел главный недостаток программы в том, она будто бы защищала крупные землевладения. Это обвинение падало «само собой, так как все арендные земли» подлежали отчуждению, а все земли, обрабатываемые владельцем, также отчуждались «по мере настоятельной необходимости по постановлению местных комиссий». Исключение составляли лишь некоторые «частновладельческие земли, имеющие в хозяйственном отношении культурное значение».

Лев Дмириевич Брюхатов, делегат из Тамбова, находил «тезисы комиссии неудовлетворительными» потому, что отчуждение должно было «иметь в своей основе настоятельную земельную нужду крестьян». При этом он стоял «также за национализацию земли», однако считал «ее неосуществимой в данный момент».

Федор Измайлович Родичев «самым решительным образом» высказался «против тезисов комиссии», ибо если «говорим, что отчуждать и оценивать земли будут комиссии, но кто будет в их составе? Крестьяне? Земство? Но ведь там будут и земские начальники, и судьи», и другие правительственные представители. «Но верите ли вы», - спрашивал он, - что они «способны будут решать подобные вопросы? Я им не верю, так как я их знаю». Эти комиссии не способны будут решать вопросы «ни с субъективной, ни с объективной точки зрения». Кадеты - «партия демократическая и должны удовлетворить насущные нужды и требования», но «мы не властны отни- 
мать у одного для другого». Если не можем «установить принцип равного наделения», то не можем совершать несправедливого поступка. Этим мы не умиротворим страну, а разрушим «экономический строй. Нельзя говорить, что этого» требовало население.

Мы стоим не за аппетиты крестьян, а должны удовлетворить и осуществить общее крестьянское право, право общенародное. Этот принции одинаков для всех.

Кадеты «сумели доказать пользу отчуждения земли, а право и основание доказать нельзя, так как права отчуждения нет». Не надо смотреть неправильно. «Крестьяне жаждут частной собственности, земельного надела, - продолжал оратор, - а другого надела (деньгами)» жаждут землевладельцы. «Окраины - Малороссия и запад - требуют сохранения права личной собственности». Необходимо установить право аренды и требовать «уменьшения арендной платы», что будет

справедливо для всех. Уравнения земли можно достигнуть введением прогрессивного поземельного налога. Итак, наши требования должны быть совершенно справедливы, соответственны правосознанию народа и вполне осуществимы.

Делом кадетской партии - «установить право, а делить чужую собственность - это подвиг Чингисхана!». В заключении Родичев предложил, чтобы выработанные тезисы «в программу не вносить» ${ }^{8}$.

Кн. Е.Н. Трубецкой возражал Ф.И. Родичеву, что его взгляд «на деятельность местных комиссий слишком пессимистичен». Крестьяне были «слишком возбуждены», поэтому

необходимо признать отчуждение и учреждение комиссий на местах. Положение России можно сравнить с большим ярким пожаром, и для тушения этого пожара кадеты имели только маленький дырявый насос. Нужно ли нам ждать, пока нам привезут из-за границы усовершенствованный западноевропейский паровой насос, построенный по всем правилам техники? Этот маленький, негодный насос - это наша Государственная Дума. Нет, ждать нельзя, крестьяне ждать не будут, они надумают «свою думу»!

Надо тушить пожар всеми возможными средствами». Затем оратор убеждал, что

с уничтожением частной собственности наступит варваризация хозяйства; уничтожить сразу частную собственность нельзя, но ограничить ее можно. Она выиграет в интенсивности 9 .

${ }^{8}$ Съезды и конференции Конституционно-Демократической Партии, t. 1, 1905-1907 г2., c. $140-141,147$.

${ }^{9}$ Съезды и конференции Конституционно-Демократической Партии, t. 1, 1905-1907 г2., c. $141-142$. 
Людвиг Владиславович Гантовер из Петербурга высказался за создание новой программы в крестьянском вопросе, которая

должна быть построена совершенно независимо от бурного времени, не должна быть продиктована страхом перед новыми аграрными беспорядками, тем более что страх вообще плохой советчик.

Оратор выступал против отчуждения земли, ибо,

с точки зрения партии, демократизация землевладения должна совершаться не при помощи нарушения приобретенных прав, а при помощи постепенной эволюиии, которой должны подвергаться поземельные отномения, благодаря тем разным мерам, которые проникнуты идеями гуманности и справедливости.

По мнению Бориса Ефремовича Гисена из Могилевской губернии, для утоления «острого аграрного голода русского крестьянства» необходимо было включить в программу следующие пункты:

1) отчуждение местечковых усадебных земель для всех тех, которые ими теперь пользуются, и 2) наделение местечек выгонными и пастбищными землями посредством выкупа на счет казны.

Владимир Владимирович Пржевальский, делегат из Москвы, не соглашался с Родичевым и сказал, что тот «вносит страстность в вопрос, в котором необходимо все хладнокровие рассудка». Оратор указал, что отчуждение не противоречило основе права, ибо оно

есть равнодействующая хозяйственных и экономических условий, которые возводятся в правовые формы. Правовое государство раздает земли на основании трудоспособности.

Он предлагал оставить решение аграрного вопроса Государственной Думе. Делегат из Подольской губернии защищал право частной собственности и был против отчуждению потому, что земли, «арендуемые под сахарные заводы», давали крестьянам большой доход, поэтому «отчуждение их вредно отразится на их благосостоянии».

Делегат из Полтавской губернии указал на неясности в программе, касающиеся «уплаты за отчужденные земли» и «потребное» количество. И для Алексея Владимировича Десятова, делегата из Харькова, были неясности в программе. Он спрашивал: «Что можно подразумевать под словом «землепользование»?». Десятов высказался за государственный фонд, ибо «государство же должно отдавать землю в пользование», а кадеты «не должны допустить, чтобы земля стала бы продажной». Оратор призывал «принять самые энергичные меры для успокоения аграрных волнений, организовать 
комитеты для разрешения вопроса» и внести в программу изменения, так как работа на местах без этого «будет затруднительна».

Иван Васильевич Лучицкий, делегат из Киева, решительно протестовал против национализации земли и доказывал, что этот принцип невозможен для Малороссии, где крестьяне «в течение целого столетия» владели «индивидуальной собственностью». Они никогда не согласятся «на отчуждение земли в пользу государства, пропаганда национализации не будет иметь там успеха»

А.А. Кизеветтер указал, что, «при условии вознаграждения за отчуждаемую землю из общегосударственных средств, должно будет распоряжаться землями государство». Делегат Быковский высказался за программу и за сохранение $\S 37$.

Василий Семенович Соколов, председатель уездной земской управы в Костромской губернии, убеждал участников съезда, «что вопроса до Государственной Думы откладывать нельзя».

Подводя итоги дискуссии, П.Н. Милюков поддержал заявление Родичева на той основе, что в противном случае «пункты программы явятся в противоречии друг другу». Он пришел к выводу, что результаты работы комиссии не встретили поддержки на съезде. Поэтому прежде чем приступить к баллотировке по аграрному вопросу, лидер кадетов обратился к делегатам, к их политическому благоразумию и просил «не принимать таких категорических постановлений, которые были бы неприемлемы» для части членов партии и «привели бы к ее распаду» ${ }^{10}$.

Иван Ильич Петрункевич, член ЦК, предложил, чтобы «остаться при старой программе», в противном случае «партия потеряет свое значение».

Председательствующий, М.М. Винавер, поставил на баллотировку предложение оставить раздел VI «Аграрное законодательство» программы без изменений. За предложением проголосовало большинство в 71 человек и на этом обсуждение аграрного вопроса было закончено ${ }^{11}$.

Впоследствии П.Н. Милюков признал, что принципиальные вопросы, и в том числе об общем земельном фонде и его употреблении, были обойдены или затушёваны в программных формулировках. «Их решение предоставлялось будущему». Он считал, что так кадеты «вышли из программных разногласий» ${ }^{12}$

Но это имело и свои негативные последствия для кадетов. В марте 1906 года состоялись выборы в Первую Государственную Думу. Несмотря на то, что в неё было избрано 179 кадетов, - 42,5\% всего её состава и они стали

${ }_{10}$ Съезды и конференциии Конституц̧ионно-Демократической Партии, t. 1, 1905-1907 г2., c. $146-147$.

11 Съезды и конференции Конституциионно-Демократической Партии, t. 1, 1905-1907 г2., с. 149.

12 П.Н. Милюков, Воспоминания. Том первый. (1859-1917), Москва, 1990, с. 314. 
были самой большой фракцией в парламенте, крестьянство на выборах игнорировало эту партию. По данным самих кадетов, - писал Валентин Валентинович Шелохаев, - за них на выборах в I Думу проголосовало только $4 \%$ крестьян ${ }^{13}$. Как признал П.Н. Милюков, «крестьяне уже знали, чего они хотели» ${ }^{14}$.

Аграрная программа кадетов отпугивала крестьян. Конституционно-Демократическая Партия на учредительском съезде в октябре 1905 года в свою программу включила раздел о аграрном вопросе, используя программу, выработанную Союзом Освобождения ещё в марте 1905 года ${ }^{15}$. И хотя на заседаниях ЦК, и на съездах партии раздавались голоса о необходимости изменений в аграрной программе, все же большинство руководителей кадетов не решились пойти на это. И только тогда, когда оказалось, что крестьяне не поддержали кадетскую партию на выборах в законодательные учреждения, она приступила к выработке новой программы по аграрному вопросу.

\section{Edward Wiśniewski}

\section{PIERWSZY PROGRAM AGRARNY PARTII KONSTYTUCYJNO- -DEMOKRATYCZNEJ}

Powstała w październiku 1905 roku Partia Konstytucyjno-Demokratyczna na swoim pierwszym zjeździe przyjęła program, w którym również znalazły się punkty dotyczące kwestii chłopskiej. Między innymi proponowano bezrolnym i małorolnym chłopom przydzielenie ziemi państwowej i apanażowej, a także częściowe uwłaszczenie ziemi obszarniczej za wynagrodzeniem dotychczasowym właścicielom w tych regionach, gdzie by jej nie wystarczało. Postulowano utworzenie państwowego funduszu ziemi, przesiedlanie chłopów i uregulowanie kwestii dzierżawy. Program ten na posiedzeniu Komitetu Centralnego i na drugim zjeździe partii w styczniu 1906 roku uznano za niewystarczający i proponowano jego zmianę. Jednak liderzy partii z Pawłem Milukowem na czele uznali, że nie należy dokonywać żadnych zmian, co odbiło się na rezultatach wyborów do I Dumy Państwowej w 1906 roku, kiedy tylko 4\% chłopów głosowało na partię kadetów.

${ }_{13}$ В.В. Шелохаев, Кадеть - главная партия либеральной буржуазии в борьбе с револючией 1905-1907 г2., Москва 1983, с. 182.

${ }_{14}$ П.Н. Милюков, Воспоминания. Том первый. (1859-1917), с. 359.

${ }^{15}$ Политические партии России. Конеи ХIX- первая треть XX века. Документальное наследие. 1902-1905 г2., Москва 2001, с. 161. 


\section{Edward Wiśniewski}

\section{THE FIRST AGRARIAN PROGRAM OF THE CONSTITUTIONAL DEMOCRATIC PARTY}

The Constitutional Democratic Party, which was established in October 1905, during its First Congress adopted a program that took into consideration the peasant issue. Among many others, party members proposed landless peasants and smallholders to allocate state and appanage land as well as partial enfranchisement of lands, with refund paid to its owners in the regions with no land to offer. They postulated the creation of a state fund land, resettlement of peasants and regulation of the lease. The program in question was declared insufficient at the meeting of the Central Committee and the Second Party Congress in January 1906.

However, party leaders with Paul Miliukov amongst them, decided that no changes should be implemented, which gravely affected the results of the elections to the State Duma in 1906 with only $4 \%$ of farmers voting for the party of cadets.

Słowa kluczowe: Rosja, chłopi, partia.

Keywords: Russia, peasants, party.

\section{BIBLIOGRAFIA}

Государственный Архив Российской Федерации в Москве (ГАРФ):

- ф. 102 Департамент Полиции, оп. 1905, д. 999 часть 43, Программа Конституционно-Демократической Партии выработанная учредительным съездом партии 12-18 октября 1905 года, л. 88.

- ф. 523 Конституционно-Демократической Партии, оп. 1, д. 27, л. 9.

Протоколь Центрального Комитета Конституиионно-Демократической Партии, t. 1, 1905-1911 г2., Москва 1994.

Съеды и конференции Конституционно-Демократической Партии, t. 1, 1905-1907 гг., Москва 1997.

Милюков П.Н., Воспоминания. Том первый. (1859-1917), Москва 1990.

Политические партии России. Конеи ХIX - первая треть ХХ века. Документальное наследие. 1902-1905 гг., Москва 2001.

Кизеветтер А.А., На рубеже двух столетий. Воспоминания, 1881-1914, Москва 1997.

Шелохаев В.В., Кадеты - главная партия либеральной буржуазии в борьбе с революиией 1905-1907 г2., Москва 1983. 